\title{
What happens to patients with pulmonary aspergilloma? Analysis of 23 cases
}

\author{
PAUL RAFFERTY, BEVERLEY-ANN BIGGS, GRAHAM K CROMPTON, IAN WB GRANT \\ From the Respiratory Unit, Northern General Hospital, Edinburgh
}

ABSTRACT The problems associated with pulmonary aspergilloma were assessed retrospectively in 23 patients presenting from 1953 to 1982 . Haemoptysis occurred in over half the patients and in two it was fatal. Invasive aspergillosis occurred in five patients, a higher proportion than in earlier reports, and two of these died. Amphotericin B in combination with either flucytosine or natamycin and, more recently, ketoconazole have proved useful in the treatment of this condition.

Species of aspergillus fungi are found throughout the world in decaying vegetation and soil, and its spores are ubiquitous in rural and urban environments. The first report of pulmonary aspergillosis in man appeared in $1842^{1}$ and several patterns of the disease have since been recognised, ${ }^{2}$ ranging from colonisation of damaged lung tissue by the fungus to invasive or necrotising pulmonary aspergillosis. ${ }^{3}$ The most distinctive lesion is the aspergilloma, ${ }^{4}$ which forms when the fungus grows on the wall of a lung cavity and mycelium and debris become detached to form a concretion of amorphous material containing tangled septate hyphae and altered blood elements.

The natural history of pulmonary aspergilloma is poorly documented and there is no general agreement on the best form of management. This report analyses the treatment and outcome of all cases seen at the Northern General Hospital, Edinburgh, during the past 30 years.

\section{Patients}

Twenty-three patients with aspergilloma were studied in the period 1953-82. The criteria for a diagnosis of aspergilloma consisted of the classical radiological sign of an intracavitary mass with a surrounding crescent of air and either a positive result in the aspergillus precipitin test, a sputum culture positive for aspergillus, or (in most cases) both.

The patients ranged in age from 40 to 81 years,

Address for reprint requests: Dr Paul Rafferty, Respiratory Unit, Northern General Hospital, Edinburgh EH5 3BD.

Accepted 5 April 1983 with a mean of 59 years. There were 11 men and 12 women and the follow-up period varied from four months to 30 years, with a mean of 4.5 years.

\section{Results}

\section{PREDISPOSING CONDITIONS}

The commonest predisposing condition was pulmonary tuberculosis, which accounted for over twothirds of the cases; other conditions included ankylosing spondylitis, rheumatoid arthritis, ulcerative colitis, pulmonary sarcoidosis, postradiation fibrosis, lung abscess and bronchiectasis (table 1). Because of the nature and extent of the pulmonary lesions in these diseases, the lungs were often severely damaged by fibrosis and bronchiectasis before the development of the aspergilloma.

\section{SYMPTOMS AND SIGNS}

Patients most frequently presented with a productive cough, often accompanied by haemoptysis and weight loss (table 2). Half complained of dyspnoea but in most, if not all, this was related to underlying lung disease. In over half the cases finger clubbing was present.

\section{INVESTIGATIONS}

All patients had radiological evidence of an intracavitary mass separated from the surrounding wall by a crescent of air. This was often better demonstrated by tomography than by a plain posteroanterior film. Single lesions occurred with similar frequency in the two lungs. These were situated in the upper lobes in all but four patients; multiple lesions were present in six. 
Table 1 Predisposing conditions in 23 cases of pulmonary aspergilloma

\begin{tabular}{|c|c|}
\hline & No $(\%)$ of patients \\
\hline $\begin{array}{l}\text { Tuberculosis* } \\
\text { Ankylosing spondylitis } \\
\text { Sarcoidosis } \\
\text { Rheumatoid arthritis } \\
\text { Ulcerative colitis } † \\
\text { Postradiation fibrosis } \ddagger \\
\text { Lung abscess } \\
\text { Bronchiectasis }\end{array}$ & $\begin{array}{rr}15 & (65) \\
2 & (9) \\
1 & 4 \\
1 & 4 \\
2 & 8 \\
1 & 4 \\
1 & 4 \\
1 & (4)\end{array}$ \\
\hline
\end{tabular}

* One patient with tuberculosis later developed sarcoidosis and a bronchial carcinoma, which was successfully treated with radiotherapy.

tOne patient with ulcerative colitis also developed ankylosing spondylitis.

\$The patient with postradiation fibrosis had received radiotherapy for a malignant thymoma associated with myasthenia gravis.

Table 2 Clinical features in 23 cases of pulmonary aspergilloma

\begin{tabular}{lr}
\hline & No (\%) of patients \\
\hline Productive cough & $19(83)$ \\
Haemoptysis & $12(52)$ \\
Dyspnoea & $12(52)$ \\
Weight loss & $9(39)$ \\
Fever & $3(13)$ \\
Finger clubbing & $14(61)$ \\
\hline
\end{tabular}

Sputum samples were obtained from 22 of the 23 patients and Aspergillus fumigatus was cultured from 20. In two cases $A$ niger, $A$ terreus, and $A$ flavus were cultured in addition to $A$ fumigatus. Serum from all 23 patients was tested for $A$ fumigatus precipitins and a positive result was obtained in 20 . Of the three patients with a negative result in the precipitin test, two were on long-term corticosteroid treatment and $\boldsymbol{A}$ fumigatus was cultured from the sputum; the third developed a mycetoma with a species of Penicillium and will be the subject of a later communication.

Skinprick tests were carried out in 16 patients with a 5\% solution of an aqueous extract of $A$ fumigatus (Bencard); 13 showed positive reactions, with a wheal of more than $3 \mathrm{~mm}$ in diameter. A non-specific finding was a raised gammaglobulin level in over half the patients tested.

\section{COMPLICATIONS}

Haemoptysis occurred in 12 patients. Nine experienced recurrent haemoptysis that was slight (less than $150 \mathrm{ml}$ in 24 hours) and subsided spontaneously. Three patients had major haemoptysis (more than $500 \mathrm{ml}$ in 24 hours). One died at home; another, considered unfit for surgery, died within six hours of admission to hospital; and the third apparently responded to injections of vitamin $K$ after he had been found to have a reduced prothrombin con-
Rafferty, Biggs, Crompton, Grant

centration. Only one of these patients had a previous history of haemoptysis.

Invasive pulmonary aspergillosis developed in five patients. This diagnosis was made when progressive $\bar{\sigma}$ pulmonary shadowing was noted in the absence of $\frac{\bar{s}}{\bar{a}}$ bacterial infection and mycelial elements were pres- $\overparen{\Phi}$ ent in the sputum. In four of these patients an aspergilloma was known to be present before the development of this complication. In the other $\vec{\circ}$ patient an aspergilloma was noted within the wider $\overrightarrow{\vec{\omega}}$ area of consolidation at the time of presentation. Three patients recovered after specific antifungal $\overrightarrow{\vec{\sim}}$ treatment and two died within 24 hours of admission. Postmortem examination confirmed the diagnosis in both patients, one of whom had evidence of systemic spread of the disease.

A more common but less specific complication, which occurred in 17 patients, was recurrent cough productive of dark green purulent sputum. $\rightarrow$ Although many patients had underlying lung disease to account for this, $A$ fumigatus was the predomin- क ant organism found on culture of the sputum in over $\vec{\imath}$ half of these cases. Three patients developed termi- $\infty$ nal respiratory failure as a result of underlying chronic lung disease and one as a consequence of myasthenia gravis (table 1).

TREATMENT AND OUTCOME The treatment of the 23 patients varied widely and $\triangle$ included antibacterial drugs, antifungal drugs, and $\overrightarrow{\vec{\sigma}}$ surgery (table 3 ). Antifungal treatment included, either singly or in combination, natamycin by inhalation, clotrimazole, and ketoconazole by mouth and amphotericin, flucytosine (5FC), and econazole by intravenous infusion. None of these treament regimens reduced the size of the aspergilloma, but in $\stackrel{x}{x}$ some cases they relieved troublesome cough and haemoptysis. The mortality in treated and untreated patients was similar. Patients with purulent sputum were often given antibacterial chemotherapy initially, but if $A$ fumigatus was found to be the predominant pathogen treatment with a specific antifungal $D$ agent was usually substituted. In one of two patients with haemoptysis who were treated with ampicillin $N$ for suspected bacterial infection the aspergilloma temporarily disappeared, and in the other it became $O$ smaller. In one patient treated with prednisolone $\omega$ there was symptomatic improvement and a reduction in size of the aspergilloma.

Specific antifungal chemotherapy was given to eight patients without invasive aspergillosis on account of purulent sputum or haemoptysis associ- $\frac{T}{T}$ ated with a heavy growth of $A$ fumigatus in the $\underset{\mathbb{D}}{\stackrel{O}{D}}$ sputum. The symptoms resolved in six of these $\stackrel{\square}{\square}$ patients, but in all eight the aspergilloma remained $\stackrel{\mathbb{Q}}{\varrho}$ unchanged. Five patients with invasive aspergillosis 0 
Table 3 Treatment and outcome in 23 cases of pulmonary aspergilloma

\begin{tabular}{|c|c|c|c|c|c|}
\hline Treatment & $\begin{array}{l}\text { No of } \\
\text { patients }\end{array}$ & Indication & $\begin{array}{l}\text { Response to } \\
\text { treatment }\end{array}$ & $\begin{array}{l}\text { Effect on } \\
\text { aspergilloma }\end{array}$ & Outcome \\
\hline $\begin{array}{l}\text { Antifungal } \\
\text { Clotrimazole }\end{array}$ & 3 & Cough, sputum & Improvement in 2 & Unchanged & $\begin{array}{l}1 \text { died (invasive } \\
\text { aspergillosis) } \\
1 \text { died (unrelated cause) } \\
1 \text { lost to follow-up }\end{array}$ \\
\hline $\begin{array}{l}\text { Natamycin inhalation } \\
\text { Natamycin, penicillin } \\
\text { Natamycin, prednisolone } \\
\text { Natamycin, amphotericin } \\
\text { Amphotericin, flucytosine } \\
\text { Flucytosine } \\
\text { Ketoconazole } \\
\text { (+ prednisolone) }\end{array}$ & $\begin{array}{l}1 \\
1 \\
1 \\
1 \\
1 \\
1 \\
1\end{array}$ & $\begin{array}{l}\text { Cough, sputum } \\
\text { Cough, sputum } \\
\text { Cough, sputum } \\
\text { Invasive aspergillosis } \\
\text { Invasive aspergillosis } \\
\text { Cough, sputum } \\
\text { Invasive aspergillosis }\end{array}$ & $\begin{array}{l}\text { Symptoms resolved } \\
\text { Symptoms resolved } \\
\text { Symptoms resolved } \\
\text { Symptoms resolved } \\
\text { Symptoms resolved } \\
\text { Symptoms persisted } \\
\text { Symptoms resolved }\end{array}$ & $\begin{array}{l}\text { Unchanged } \\
\text { Unchanged } \\
\text { Unchanged } \\
\text { Smaller } \\
\text { Unchanged } \\
\text { Unchanged } \\
\text { Unchanged }\end{array}$ & $\begin{array}{l}\text { Died (unrelated cause) } \\
\text { Lost to follow-up } \\
\text { Died (unrelated cause) } \\
\text { Died (haemoptysis) } \\
\text { Alive } \\
\text { Died (unrelated cause) } \\
\text { Alive }\end{array}$ \\
\hline $\begin{array}{l}\text { Ketoconazole } \\
\text { Econazole }\end{array}$ & $\begin{array}{l}1 \\
1\end{array}$ & $\begin{array}{l}\text { Haemoptysis } \\
\text { Invasive aspergillosis }\end{array}$ & $\begin{array}{l}\text { Symptoms resolved } \\
\text { Deteriorated rapidly }\end{array}$ & $\begin{array}{l}\text { Unchanged } \\
\text { Unchanged }\end{array}$ & $\begin{array}{l}\text { Alive } \\
\text { Died (invasive } \\
\text { aspergillosis) }\end{array}$ \\
\hline $\begin{array}{l}\text { Surgical } \\
\text { Local resection } \\
\text { Right upper lobectomy }\end{array}$ & $\begin{array}{l}1 \\
1\end{array}$ & $\begin{array}{l}\text { Haemoptysis } \\
\text { Haemoptysis }\end{array}$ & $\begin{array}{l}\text { Chronic empyema } \\
\text { Bronchopleural fistula }\end{array}$ & $\begin{array}{l}\text { Resected } \\
\text { Resected }\end{array}$ & $\begin{array}{l}\text { Alive } \\
\text { Died (postoperative } \\
\text { respiratory failure) }\end{array}$ \\
\hline $\begin{array}{l}\text { Non-specific } \\
\text { Prednisolone } \\
\text { Antibacterial drugs only }\end{array}$ & $\begin{array}{l}1 \\
3\end{array}$ & $\begin{array}{l}\text { Haemoptysis } \\
\text { Cough, sputum }\end{array}$ & $\begin{array}{l}\text { Symptoms resolved } \\
\text { Symptoms resolved }\end{array}$ & $\begin{array}{l}\text { Smaller } \\
\text { Lysis in } 1\end{array}$ & $\begin{array}{l}\text { Alive } \\
1 \text { died (haemoptysis) } \\
2 \text { died (unrelated causes) }\end{array}$ \\
\hline Vitamin $\mathbf{K}$ & 1 & Haemoptysis & Symptoms resolved & Unchanged & Alive \\
\hline None & 4 & Asymptomatic & & Unchanged & $\begin{array}{l}1 \text { alive } \\
1 \text { lost to follow-up } \\
2 \text { died (unrelated causes) }\end{array}$ \\
\hline
\end{tabular}

were also treated with antifungal drugs. In all three survivors the chemotherapy included amphotericin or ketoconazole.

Two patients were treated surgically, both for recurrent haemoptysis. The first developed a chronic empyema and the second died from respiratory failure in the postoperative period, having developed a bronchopleural fistula.

In the whole group of 23 patients five deaths were directly attributable to the aspergilloma. Two of these were due to invasive aspergillosis and two to massive haemoptysis, and one followed surgery for recurrent haemoptysis. Three patients died from respiratory failure, two from bronchial carcinoma, one from intestinal malabsorption, and two at home from unknown causes. Seven are currently alive and the remaining three have been lost to follow-up.

\section{Discussion}

The reasons why the natural history of intracavitary aspergilloma is poorly documented are that it is an uncommon disease and that the outcome is so often related to underlying non-specific pulmonary pathology. The most common predisposing condition in our patients was tuberculosis. This is in keeping with the findings of the British Tuberculosis Association, which in 1968 reported the develop- ment of an aspergilloma in $15 \%$ of persisting (sputum-negative) cavities larger than $2.5 \mathrm{~cm}$, the highest incidence being found in cavities of 7-11 years' duration. ${ }^{5}$

Most patients have a chronic productive cough and occasionally develop the systemic features of fever, malaise, and weight loss. It is difficult to know whether these symptoms are due to the aspergilloma or to coexisting bacterial infection. Davies and Somner suggested that such symptoms may be due to a hypersensitivity reaction to aspergillus. ${ }^{6}$ This is supported by the similarity of the pattern of cytophilic antibodies found in these patients and in those with allergic bronchopulmonary aspergillosis. ${ }^{7}$

Haemoptysis, a well-recognised complication of aspergilloma, occurred in over half of our patients. Of these, only two succumbed from massive bleeding. The frequency and severity of previous haemoptysis appeared to have little bearing on the final outcome. Other authors have reported lifethreatening haemoptysis in $20 \%$ of patients with aspergilloma and suggest that these patients should be treated surgically. ${ }^{8}$ In our experience, however, this is seldom feasible because most patients with aspergilloma have severely damaged lungs and poor pulmonary function.

A more disturbing complication is that of invasive pulmonary aspergillosis (fig). This occurred in five of 

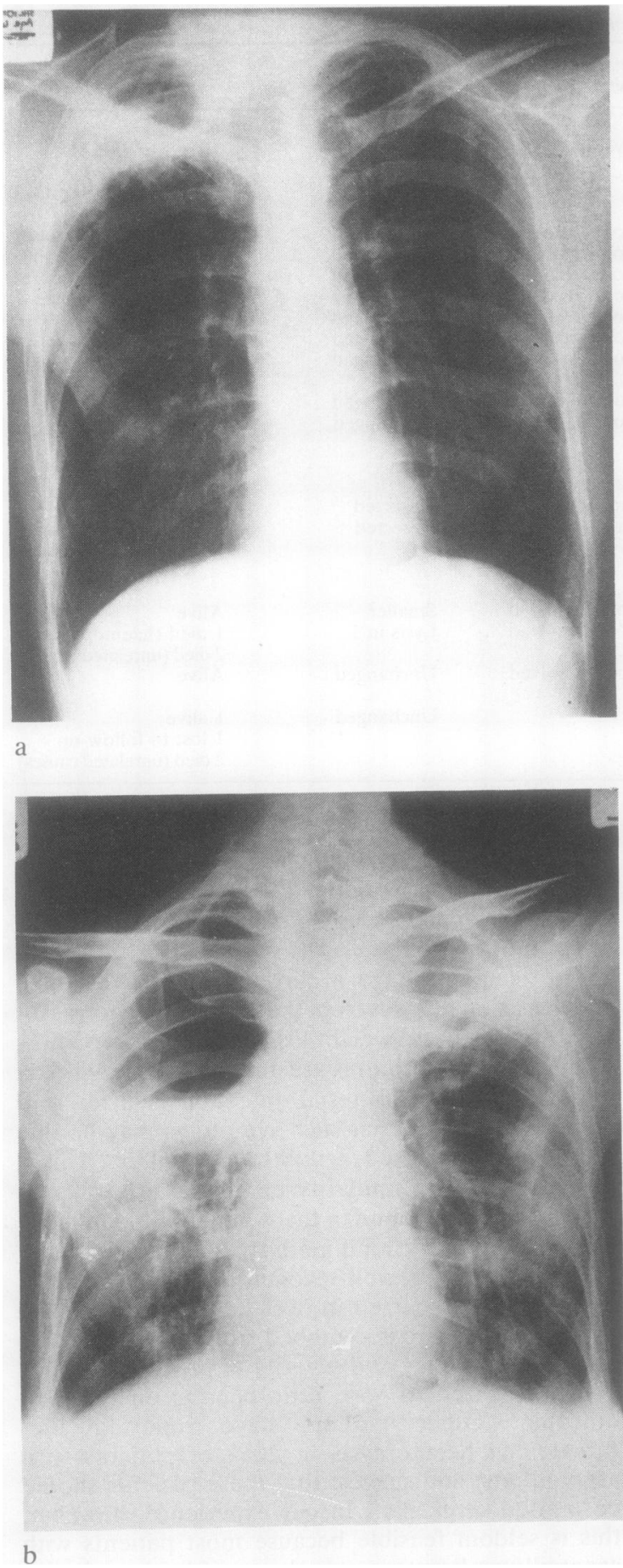

(a) Pulmonary aspergilloma in the right upper lobe. (b) Subsequent development of invasive aspergillosis in the same patient. our patients, two of whom died. This condition is usually found in debilitated or immunosuppressed $\stackrel{5}{\rightarrow}$ patients. Four of our patients were in this category: two were receiving corticosteroid treatment and one had chronic empyema and the other ulcerative colitis. These findings are at variance with the experience of other workers, ${ }^{9}$ who suggest that the risk of in aspergilloma progressing to invasive pulmonary dis- $\vec{\circ}$ ease is negligible.

There is no general agreement on the manage- $\overrightarrow{\vec{\omega}}$ ment of pulmonary aspergilloma per se. The first $\stackrel{?}{\rightarrow}$ surgical resection was reported in $1948^{10}$ and for $\vec{x}$ many years surgery was regarded as the treatment of ${ }_{\infty}$ choice for symptomatic disease, especially in the $\%$ United States. More recently this view has been ir questioned.9 Analysis of the data from 140 pulmo- 6 nary resections for aspergilloma revealed an overall mortality of $7 \%$. Major postoperative complications such as bronchopleural fistulas, resistant air space problems, empyema, and haemorrhage occurred in $22 \%$ of cases. The two patients in our own series $\stackrel{\varrho}{+}$ who were treated surgically fared badly. One died $\vec{\oplus}$ and the other was left with chronic empyema.

Antifungal treatment in this series varied considerably from case to case and did not affect the size of the aspergilloma or mortality. Our experience, however, confirmed the potential value of amphotericin combined in some cases with flucytosine, and poss- $\mathbb{Q}$ ibly of ketoconazole, in the treatment of secondary $\vec{F}$ invasive aspergillosis. Ketoconazole is an oral anti-은 fungal agent in the imidazole group, which has been $\supset$ shown to be effective in various superficial fungalo infections and some systemic ones. Borelli et al have reported that two patients with pulmonary asperg-ô illoma failed to respond to treatment with ketoconazole; ${ }^{11}$ but we used it successfully in one patient with invasive aspergillosis, and in another patient symptomatic improvement coincided with the virtual elimination of $A$ fumigatus from the sputum.

This study exemplifies the unsystematic approach to the treatment of pulmonary aspergilloma duringo the past three decades, and the high mortality raten underlines the inadequacy of both medical and sur-? gical treatment. There is very little evidence that either form of treatment influences the prognosis except on the rare occasions when the risk of fatab haemoptysis can be eliminated by resection of the aspergilloma or when secondary invasive pulmonary aspergillosis, a more common complication than iș? generally recognised, can be controlled by intensive antifungal chemotherapy.

\section{References}

${ }^{1}$ Bennet JH. On the parasitic vegetable structures found 

growing in living animals. Trans $R$ Soc Edinb 1842;15:277.

2 Turner-Warwick M. Aspergillus fumigatus and lung disease. Postgrad Med J 1979;55:642-4.

${ }^{3}$ Kennedy WPU, Malone DN, Blyth W. Necrotising pulmonary aspergillosis. Thorax 1970;25:691.

4 Campbell MJ, Clayton YM. Bronchopulmonary aspergillosis: a correlation of the clinical and laboratory findings in 272 patients investigated for bronchopulmonary aspergillosis. Am Rev Respir Dis 1964;89:186-96.

5 Research Committee of the British Tuberculosis Association. Aspergillus in persistent lung cavities after tuberculosis. Tubercle 1968;49:1.

- Davies D, Somner AR. Pulmonary aspergillomas treated with corticosteroids. Thorax 1972;27:156-62.
' Assem ESK, Turner-Warwick M. Cytophilic antibodies in bronchopulmonary aspergillosis, aspergilloma and cytogenic pulmonary eosinophilia. Clin Exp Immunol 1976;26:67.

${ }^{8}$ Karas A, Hankins JR, Attar S, Miller JE, McLaughlin JS. Pulmonary aspergillosis: an analysis of 41 patients. Ann Thorac Surg 1976;22:1-7.

9 Varkey B, Rose HD. Pulmonary aspergilloma: a rational approach to treatment. Am J Med 1976;61:626-31.

${ }^{10}$ Gerstl B, Weidman WH, Newman AV. Pulmonary aspergillosis: a report on 2 cases. Ann Intern Med 1948;26:661.

${ }^{11}$ Borelli D, Fuentes J, Leiderman E, et al. Ketoconazole, an oral antifungal: laboratory and clinical assessment of imidazole drugs. Postgrad Med J 1979;55:657-61. 